\title{
Floods and consequential life cycle assessment: integrating flood damage into the environmental assessment of stormwater Best Management Practices
}

Anna Petit-Boix ${ }^{\mathrm{a}, *}$, Eva Sevigné-Itoiz ${ }^{\mathrm{b}}$, Lorena A. Rojas-Gutierrez ${ }^{\mathrm{c}}$, Ademir P. Barbassa $^{\mathrm{d}}$, Alejandro Josa ${ }^{\mathrm{e}, \mathrm{f}}$, Joan Rieradevall ${ }^{\mathrm{a}, \mathrm{g}}$, Xavier Gabarrell ${ }^{\mathrm{a}, \mathrm{g}}$

aSostenipra (ICTA-IRTA-Inèdit; 2014 SGR 1412) Institute of Environmental Science and Technology (ICTA; Unidad de excelencia «María de Maeztu» (MDM-2015-0552)), Universitat Autònoma de Barcelona (UAB), Edifici ICTA-ICP, Carrer de les Columnes, 08193 Bellaterra, Barcelona, Spain.

${ }^{b}$ Centre for Environmental Policy, Imperial College London. 13's Prince's Gardens, South Kensington, London SW7 2AZ, UK

'Sanitary and Hydraulics Engineering Department, University of São Paulo (USP), Avenida Trabalhador sãocarlense, 400, Parque Arnold Schimidt, 13566-590, São Carlos, SP, Brazil

${ }^{\mathrm{d} C i v i l ~ E n g i n e e r i n g ~ D e p a r t m e n t, ~ F e d e r a l ~ U n i v e r s i t y ~ o f ~ S a ̃ o ~ C a r l o s ~(U F S C a r), ~ R o d o v i a ~ W a s h i n g t o n ~ L u i ́ s, ~ k m ~} 235$ SP-310, 13565-905, São Carlos, SP, Brazil

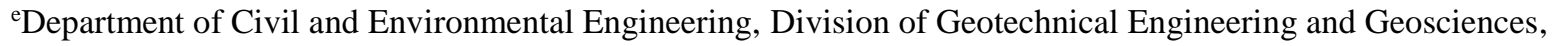
School of Civil Engineering, Universitat Politècnica de Catalunya (UPC-BarcelonaTech), Jordi Girona 1-3, Building D2, Barcelona, Spain.

fInstitute of Sustainability (IS.UPC), Universitat Politècnica de Catalunya (UPC-BarcelonaTech), Jordi Girona 31, Barcelona, Spain

${ }^{g}$ Department of Chemical, Biological and Environmental Engineering, Xarxa de Referència en Biotecnologia (XRB), School of Engineering (ETSE), Universitat Autònoma de Barcelona (UAB), Campus of the UAB, Bellaterra (Cerdanyola del Vallès), 08193 Barcelona, Catalonia, Spain.

*Corresponding author: Anna Petit Boix (anna.petit@uab.cat). Sostenipra (ICTA-IRTA-Inèdit; 2014 SGR 1412), Institute of Environmental Science and Technology (ICTA; Unidad de excelencia «María de Maeztu» (MDM-20150552)), Universitat Autònoma de Barcelona (UAB), Edifici ICTA-ICP, Carrer de les Columnes, 08193 Bellaterra, Barcelona, Spain.

Post-print of Petit-Boix, Anna et al. «Floods and consequential life cycle assessment: Integrating flood damage into the environmental assessment of stormwater Best Management Practices» in Journal of cleaner production (ScienceDirect). Vol 162 (September 2017), p. 601-608). The final version is available at DOI 10.1016/j.jclepro.2017.06.047 


\section{ABSTRACT}

Stormwater management is essential to reducing the occurrence of flooding events in urban areas and to adapting to climate change. The construction of stormwater Best Management Practices (BMPs) entails a series of life cycle environmental impacts but also implies avoided burdens, such as replacing urban infrastructure after flooding. The aim of this paper is to integrate flood damage prevention into the life cycle assessment (LCA) of BMPs for quantifying their net environmental impact (NEI) and environmental payback (EP) from a consequential LCA standpoint. As a case study, the application of a filter, swale and infiltration trench (FST) in a Brazilian neighborhood was assessed considering a high-intensity rainfall event. The potential avoided impacts were related to cars and sidewalks that were not destroyed due to flooding. In terms of $\mathrm{CO}_{2}$ eq. emissions, the environmental investment related to the FST was recovered when the destruction of one car or $84 \mathrm{~m}^{2}$ of sidewalk was prevented. The NEI of the FSTs resulted in significant impact reductions (up to $700 \%$ ) with respect to not accounting for the avoided products. This approach can be implemented to any type of BMP, and more accurate estimations can be made with data for different events and different types of material damage.

KEYWORDS: flood, BMP, CLCA, urban infrastructure, water, city 


\section{INTRODUCTION}

Flood risk management is crucial in several parts of the world. From 1960 to 2014, flooding events accounted for $34 \%$ of the natural disasters registered worldwide (17 floods/year), representing more than 2.5 billion USD/year in terms of monetary damage and 1,254 deaths/year (Guha-Sapir et al., 2009). Currently, 53\% of the world's population lives in urban areas (The World Bank, 2016), a figure that is expected to increase to $70 \%$ by 2020 (UN, 2012), implying an increasing demand for new construction and infrastructure, and decreasing the proportion of permeable areas and sometimes improper land-use planning (Jha et al., 2012). Combined with a forecasted increase in the precipitation intensity, this increase would result in a greater risk of potential flooding events, especially in mid and high latitudes (Meehl et al., 2007). Most of the major flooding events that have been recorded occur in highly populated urban areas (Jha et al., 2011).

Therefore, there is a need for proper stormwater management practices in cities to reduce the occurrence and consequences of these events. To do so, stormwater Best Management Practices (BMPs) are commonly used and at present are usually classified into gray and green infrastructure BMPs. Gray infrastructure BMPs are traditional drainage strategies (e.g., sewers or detention tanks), whereas green infrastructure BMPs provide ecosystem services, such as aquifer recharge or environmental restoration (European Commission, 2013). Examples of green BMPs include decentralized systems, such as green roofs, permeable pavements, bio-retention basins and rainwater harvesting systems, among others.

In the context of Low-Impact Development (LID), these techniques are based on the premise that stormwater management should not be envisioned as stormwater disposal. Implementing sourcecontrol BMPs might result in a reduction of the flooding risk, given that these systems can 
effectively reduce the runoff volume (Lee et al., 2013; Mentens et al., 2006; Zahmatkesh et al., 2015). Another benefit is the effect on the runoff quality. Especially green infrastructure BMPs have the potential to retain and filtrate runoff pollutants, such as heavy metals, hydrocarbons, nutrients or suspended solids (Deletic and Fletcher, 2006; Dierkes et al., 2002; Llopart-Mascaró et al., 2015). This performance depends on the type of drainage system, soil characteristics and slope (Czemiel Berndtsson, 2010), among other factors.

However, the construction of these infrastructures also entails a series of environmental impacts, such as greenhouse gas (GHG) emissions or resource depletion. To address this issue, life cycle assessment (LCA) offers a method for calculating and discussing the environmental burdens that are associated with the life cycle stages of a product or system, i.e., from raw material extraction to end-of-life (ISO 14040:2006). Several analyses have been conducted to calculate the life cycle impacts of different BMPs, such as green roofs (Kosareo and Ries, 2007; Saiz et al., 2006), bioinfiltration basins (Flynn and Traver, 2013), constructed wetlands (Risch et al., 2014), rainwater harvesting systems (Angrill et al., 2016; Devkota et al., 2015) or a combination of BMPs (De Sousa et al., 2012). These analyses mainly focus on determining the contribution of the materials and energy to the total environmental impacts of the system (i.e., attributional LCA; ALCA), as well as potential positive effects, such as carbon sequestration.

The construction of BMPs has broader consequences on the market and the society that could be assessed using consequential LCA (CLCA) (the relationship between ALCA and CLCA is presented in Section 2.1). Given that a reduction in the runoff volume results in less water being treated, some studies assessed the avoided impacts of wastewater treatment plants (WWTP) (Catalano De Sousa et al., 2011; Spatari et al., 2011; Wang and Zimmerman, 2015). In another 
study, Wang et al. (2013) calculated the economic and environmental impacts related to reducing the eutrophication for different BMP combinations, such as bio-retention basins or separate stormwater networks. Nevertheless, the lack of studies that include CLCA in the assessment of BMPs hinders the effects of BMP implementation at an urban scale and from a life cycle perspective. Implementing a certain type of BMP for preventing urban flooding might also prevent the destruction of goods that would otherwise need to be replaced. In such scenario, the impacts associated with the production of the affected goods would be avoided (e.g., urban infrastructure, buildings, etc.). However, given that a previous environmental investment was made to produce the BMP, the net balance between impacts and benefits should be determined. This approach was already applied considering the net environmental impact (NEI) as the difference between the avoided and induced eutrophication potential in WWTPs (Lorenzo-Toja et al., 2015), and in the damage evolution resulting from post-disaster emergency actions implemented in ephemeral streams after flooding (Petit-Boix et al., 2016).

Additionally, the NEI might vary depending on the type of BMP and the area of application. This analysis is especially interesting in flood-sensitive countries. A particular study area could be Brazil, where there are great variations between social strata and urban densities, a fact that might influence the space that is available for constructing a BMP. In this country, floods account for $60 \%$ of the total natural disasters and an average of 200 million USD in terms of damage (GuhaSapir et al., 2009). Additionally, the number of flooding events has generally increased over time (Guha-Sapir et al., 2009) and may increase in the future because of climate change. Given a certain urban density, the implementation of a BMP could be analyzed in a Brazilian neighborhood. In this paper, the BMP that was selected for a first case study analysis was a filter, swale and infiltration trench (FST) that had been previously constructed in a Brazilian city for experimental 
purposes. The specific design features and storage capacity of this BMP were thoroughly analyzed in previous studies (Lucas, 2011; Lucas et al., 2013), and it was thus applied to this first assessment of flood damage prevention.

Our goal was to integrate flood damage into the LCA of stormwater Best Management Practices (BMP) for quantifying the net environmental impact (NEI) and environmental payback (EP) from a consequential LCA (CLCA) perspective. To achieve this aim, we based this analysis on a case study BMP. The specific objectives were (1) to define the steps involved in the calculation of the EP and NEI of a BMP; (2) to calculate the EP and NEI of an FST with respect to the material losses, considering the implementation of this system in Brazil; (3) to discuss the environmental implications of this approach in the field of flood prevention.

\section{MATERIALS AND METHODS}

\subsection{Consequential life cycle assessment (CLCA)}

Consequential modeling is defined as "a system modeling approach in which activities in a product system are linked so that activities are included in the product system to the extent that they are expected to change as a consequence of a change in demand for the functional unit" (Sonnemann and Vigon, 2011). In this sense, CLCA offers a causal explanation for the consequences of future actions (Weidema et al., 2009) and attempts to forecast in the short or long term the environmental impacts of decisions that are made in the present (e.g., implementing a BMP). This broader analysis is not provided by ALCA, which assesses the environmental status of a product system as an account of the history of the product (ISO 14040:2006), and does not include processes outside the product's immediate system boundaries (Earles and Halog, 2011). The ALCA 
approach analyzes the entire life cycle of a selected system but does not account for the processes that are directly or indirectly affected by the existence of this system. In contrast, the CLCA approach integrates market mechanisms into environmental modeling, which is often associated with inconsistency because LCA practitioners deal with different assumptions in their studies, such as the definition of the system boundaries (Zamagni et al., 2012). However, CLCA might help to determine certain beneficial outcomes related to the system under analysis, and to inform policymakers on the indirect environmental implications of a system (Sanchez et al., 2012; VázquezRowe et al., 2014).

The consequences of flooding vary greatly depending on their type (e.g., flash floods, coastal floods, and urban floods), location and extent of flooding, and vulnerability and value of the affected natural and constructed environment. For example, in the same area flooding events might lead to different consequences over time because of the types of built infrastructure (e.g., conventional or prevention-oriented). The impacts of flooding may include damage to properties (e.g., buildings, vehicles, roads, and public utilities), the environment (e.g., livestock or crops) and the society (e.g., casualties, damage to cultural heritage, etc.). From a CLCA system perspective, modeling should include all processes that are expected to be affected by a decision, regardless of whether they are part of the existing supply chain or not (Wolf and Ekvall, 2011). In this study, the decision of implementing BMPs for flood prevention may contribute to diminish its effects or damage. Modeling these consequences may become a very complicated and uncertain task due to the variety and unpredictability of flooding consequences and the effect of flood protection infrastructures. This is not the purpose of this analysis. This study is an attempt to highlight the potential environmental benefits related to flood prevention by including possible processes affected beyond the system evaluated (i.e., BMPs) in accordance with CLCA approaches. The 
study aspires to contribute to the flood prevention and planning debate, as strategies that decrease damage might result in important environmental savings that are currently not captured.

In our study, the effects of implementing a BMP on the market were assessed by considering a decrease in the demand for two properties (i.e., cars and sidewalks) which are generally damaged during flooding events. Both products could be representative of possible damages resulting from any type of flood and region. In this case, it is interesting to determine the trade-offs between the construction of a BMP and the material losses, assuming that these would be reconstructed after an event (Figure 1).

\subsection{Steps for calculating the environmental payback (EP) and net environmental impact (NEI) of a BMP}

This section describes the steps considered for estimating the EP and NEI of implementing a BMP for flood prevention (Figure 1).

$<$ Figure 1 $>$

Step 1 Characterization of the area and the flooding event: The main features of the study area must be collected, e.g., total area, topography, superficial and underground installations, building types and average rainfall patterns. Depending on the analyzed time period, data on a particular flooding event or a series of flooding events producing damage are needed. These data include hydrological indicators, such as rainfall intensity, duration and frequency; concentration time, water level height of rivers and reservoirs; and material losses, such as the number of cars, area of sidewalks or number of affected buildings (i.e., building structure and contents).

Step 2 Selection of the stormwater BMP: The selection of a suitable BMP for a specific area depends on different parameters, such as the features of the study area (Step 1), space and 
infiltration requirements, need for pollutant removal, land use, safety and maintenance needs (UDFCD, 2011).

Step 3 Quantification of the number of BMPs: The number of BMPs required to prevent the flooding events defined in Step 1 can be estimated as (1) the number of BMPs that could collect the total volume of stormwater, or (2) the number of BMPs that could be implemented in the area according to the space requirements. Based on hydrological parameters and a similar stormwater storage potential, the option that results in fewer BMPs is recommended. When a combination of different types of BMPs is implemented, the number of systems could be estimated through option (1), and a series of scenarios could be assessed with a varying amount of each type of BMP.

Step 4 Calculation of the environmental impacts of the BMP and avoided products: The LCA of the BMP and the avoided products is conducted based on the steps defined by ISO 14040:2006 (e.g., goal and scope definition, inventory analysis, impact assessment and interpretation). It should consider the site-specific features of the products, such as design, electricity mix, lifespan, etc.

Given that the system boundaries of this study include different elements, defining a functional unit (FU) is not straightforward (Zamagni et al., 2012). In this case, the FU could be the implementation of one or a set of BMPs, with a certain lifespan, for preventing a flooding event and its associated material damage, given a rainfall intensity of $X \mathrm{~mm} / \mathrm{h}$. If the environmental impacts of the avoided damage are assessed from an LCA standpoint, the particular impacts of each element can be related to the production of a unit of urban infrastructure (avoided product), whose destruction can be prevented by implementing a BMP. The FU should be adapted to the period of analysis, number of flooding events and rainfall intensity assessed, because the prevented 
damage is not a fixed parameter, but varies depending on the event(s) and features defined in Step 1.

Step 5 Calculation of the EP: After conducting the LCA, it is interesting to know when the environmental investment made during the implementation of the BMP might be recovered. To do so, the ratio between the impacts of one BMP and one unit of avoided product can be calculated. The results show the product units that should be prevented through the lifespan of the BMP to recover the environmental investment.

Step 6 Calculation of the NEI: The net balance per flooding event can be determined applying Equation 1. For comparing different types of BMP, the total NEI per event could be expressed in terms of NEI per cubic meter of stormwater, for instance.

Equation 1:

$$
\frac{\mathrm{NEI}}{\text { event }}=\mathrm{A} \times \frac{\text { Impact }_{\text {BMP }}}{\mathrm{L} \times \mathrm{F}}-\sum_{\mathrm{i}=1}^{\mathrm{n}}\left(\mathrm{X}_{\mathrm{i}} \times \text { Impact }_{\mathrm{i}}\right)
$$

where NEI: net environmental impact for a given impact indicator; A: number of BMPs

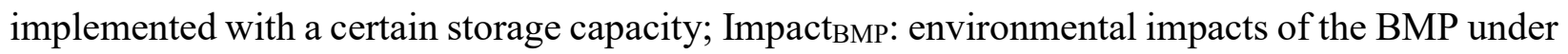
assessment; L: lifespan of the BMP (years); F: average annual flooding events; i: type of avoided product (e.g., car, sidewalk, building, etc.); X: units of avoided product per event; and Impacti: environmental impact of the avoided product.

\subsection{Case study: implementation of an FST in São Carlos (Brazil)}

The steps presented in Section 2.2 were applied to estimate the EP and NEI of a BMP in São Carlos (Brazil).

\subsubsection{Step 1 Characterization of the area and the flooding event}


São Carlos is located in the State of São Paulo (Supporting Information S1 and S2) and presents a humid Subtropical climate with an annual average rainfall of $1500 \mathrm{~mm}$ (INMET, 2014). In São Carlos, it rained 111 days every year from 2005 to 2014 on average, and the average daily rainfall during these events was $13.4 \mathrm{~mm}$ (INMET, 2014), with a maximum in $118 \mathrm{~mm}$ (Supporting Information S3). On average, São Carlos experiences three heavy rainfall events every year that result in a flood and damage to the environment (Supporting Information S4). The built environment is typically affected by the destruction of roads, sidewalks, roofs, walls, public utilities and vehicles. In São Carlos, there are also records of injuries, deaths and destruction of homes after flooding (IPMet, 2014).

For the purpose of this assessment, data from one of the flooding events presented in Supporting Information $\mathbf{S 3}$ were applied. To assess an extreme event with high-intensity rainfall $(>30 \mathrm{~mm} / \mathrm{h}$ - FLOODsite (2008)) that produced damage, data from October 22, 2013 were analyzed. During this event, $50 \mathrm{~mm}$ of rainfall were recorded in $15 \mathrm{~min}(200 \mathrm{~mm} / \mathrm{h})$, resulting in the destruction of 6 cars and 50 sidewalk stretches with an average area of $3 \mathrm{~m}^{2}$ each (IPMet, 2014). These data were retrieved from the Natural Disaster Database of the Institute of Meteorological Research (IPMet, 2014), which is responsible for recording disaster damage in Brazil. Given the difficulties in data gathering, very little information exists on the volume of losses, although the type of damage is reported. As a result, the estimation of the NEI and EP only focused on this specific flooding event, for which data were available, with the purpose of exemplifying the application of this approach.

\subsubsection{Step 2 Selection of the stormwater BMP}

To reduce the number of floods and their consequences, a pilot green stormwater BMP was built in 2009 on the campus of the Federal University of São Carlos (UFSCar). In this case, the BMP was an FST that occupied $600 \mathrm{~m}^{2}$ and had a maximum storage capacity of $110 \mathrm{~m}^{3}$, considering the 
saturation of the subsurface soil layer (for additional information, see Lucas (2011), Lucas et al. (2013) and Petit-Boix et al. (2015)). The technical requirements of the infiltration trenches are described in Baptista et al. (2005). As technical and design data of this system exist, we evaluated the hypothetical construction of a set of FSTs in a neighborhood. São Carlos has high- and lowdensity neighborhoods, and in this case, we selected the residential neighborhood Damha I (RDI) because (1) it could benefit from a decentralized, green stormwater management as an alternative to combined sewers, and (2) this area can host FSTs given the space requirements, as it is a lowdensity neighborhood. RDI covers an area of 420,000 $\mathrm{m}^{2}$ and consists of single-house blocks with green plots that could potentially host an FST.

\subsubsection{Step 3 Quantification of the number of BMPs}

Assuming a homogeneous rainfall distribution in São Carlos, the RDI would have received 21,000 $\mathrm{m}^{3}$ of stormwater during the selected flooding event. Considering the maximum storage capacity of the FST $\left(110 \mathrm{~m}^{3}\right)$, the RDI would require 190 FSTs. Nevertheless, there were a total of 107,000 $\mathrm{m}^{2}$ worth of plots that could be used to infiltrate stormwater (Google Maps, 2015) considering gardens, abandoned green areas and plots. Given the minimum size of an FST $\left(600 \mathrm{~m}^{2}\right)$ and the dimensions of each individual plot (plots smaller than $600 \mathrm{~m}^{2}$ were excluded), set up resulted in the potential to construct 179 FSTs, which is more than $90 \%$ of the requirements of the area for that high-intensity rainfall event. In this case, 179 FSTs were accounted for in the analysis considering a homogeneous soil composition, and we assumed that they would prevent the material damage in the area.

\subsubsection{Steps 4 -6 Calculation of the environmental impacts, EP and NEI}

This step is based on the LCA methodology and is divided into the steps described in ISO 14040:2006. 
Goal and scope definition: Our specific goal was to determine the NEI and EP of implementing FSTs in RDI for flood prevention purposes. The FU considered was the implementation of 179 FSTs with a lifespan of 10 years for preventing a flooding event and its associated damage given a rainfall intensity of $200 \mathrm{~mm} / \mathrm{h}$ in a low-density neighborhood in São Carlos. We calculated the environmental impacts of producing one car and one $\mathrm{m}^{2}$ of sidewalk $(0.2 \times 1 \times 1 \mathrm{~m})$, whose destruction is prevented by the implementation of the FSTs. For the purpose of the assessment, 6 cars and $150 \mathrm{~m}^{2}$ of sidewalk were considered given the data provided by INMET (2014). The system boundaries are shown in Figure 2.

$<$ Figure 2 $>$

Inventory analysis: To account for the material and energy flows related to the life cycle of a product, a life cycle inventory (LCI) was compiled. First, the FST was assessed from cradle to grave, i.e., from the raw material extraction to the end-of-life (Figure 2). In this case, the operation phase accounted for the carbon sequestration potential. Maintenance was excluded because it was considered negligible according to the managers and was linked to the end of service life of the FST based on a previous study (Petit-Boix et al., 2015). We assumed that the system had an average lifespan of 10 years due to maintenance factors (USDT, 2014), although this value might vary depending on the management practices, runoff quality and precipitation intensity.

Second, LCIs were composed for the avoided products. In this particular case, cars and sidewalks were the damaged goods. For the environmental assessment of a compact car, we applied an LCI that combined data from different companies (Hawkins et al., 2013). Assuming that a car would be used regardless of being newly produced after the flood or being unharmed, the fuel consumption was not accounted for because these impacts would not be avoided. The estimated 
lifespan of the car was 10 years of on-road duration (Schweimer and Levin, 2000). Regarding sidewalks, we adapted the design that was presented in a previous study for one $\mathrm{m}^{2}$ of concrete sidewalks with an average lifespan of 45 years (Mendoza et al., 2012). In both cases, the end-oflife was included, given that the damaged products must be disposed of after the flooding event. All of the production processes that were included in the LCI were adapted with the marginal electricity mix for Brazil (Schmidt and Thrane, 2009), which is the most competitive technology that would be used in the production of one extra unit of product. The ecoinvent 2.2 (Frischknecht et al., 2005) database was used for retrieving background data on the life cycle of the materials and processes involved in each system. For data on the LCIs, see Supporting Information S5. In this first analysis, the impacts on land use change were not accounted for because this was already an artificialized area, and we considered that the new system provided a greater carbon sequestration potential.

Impact assessment: Of all of the stages that are included in the impact assessment stage (ISO 14040:2006, n.d.), only the classification and characterization were considered. Using the SimaPro 8.0.4 (PRé Consultants, 2010) software, the method that was applied was the hierarchical approach of ReCiPe 2008 (Goedkoop et al., 2009). The selected midpoint indicators were Climate Change (CC, $\mathrm{kg} \mathrm{CO} 2$ eq.), Ozone Depletion Potential (ODP, kg CFC-11 eq.), Terrestrial Acidification Potential (TAP, kg $\mathrm{SO}_{2}$ eq.), Freshwater Eutrophication Potential (FEP, kg P eq.), Marine Eutrophication Potential (MEP, kg N eq.), Human Toxicity Potential (HTP, kg 1,4-DB eq.), Photochemical Oxidant Formation Potential (PCOP, kg NMVOC), Water Depletion Potential $\left(\mathrm{WDP}, \mathrm{m}^{3}\right.$ ), Metal Depletion Potential (MDP, $\mathrm{kg}$ Fe eq.) and Fossil Depletion Potential (FDP, $\mathrm{kg}$ oil eq.). The Cumulative Energy Demand V1.08 (CED, MJ) was also included to evaluate energy issues (Hischier et al., 2010). 
Interpretation: The main contributors to the impacts of the FST, car and sidewalk were analyzed. The overall results were assessed using the EP and NEI to determine the balance between the investment and avoided impacts.

\section{RESULTS}

Table 1 shows the environmental impacts of the FST and damaged products (i.e., car and sidewalk) for their respective lifespan. There were different processes that especially contributed to the burdens of each of these elements. In the case of the FST, the diesel that was consumed by the machinery accounted for $20-60 \%$ of the impacts in most of the impact categories, and the contribution of the infiltration trench was significant in 5 of 11 indicators (up to $80 \%$ of the life

cycle impacts) (Supporting Information S6). With respect to the car, steel accounted for a great share of the impacts, given that it represented $65 \%$ of the production materials in terms of mass. Copper also had an important contribution to HTP (>70\%) because of its manufacturing process. Regarding the selected sidewalk design, the concrete base and transport were the major concerns, each accounting for between 20 and $60 \%$ of the impacts.

$<$ Table 1 $>$

Applying the calculation procedure that is presented in Step 5 (Section 2.2), the EP of an FST was estimated. In terms of $\mathrm{kg}$ of $\mathrm{CO}_{2}$ eq., the environmental investment related to the FST was recovered when the destruction of one car was prevented in 10 years. Considering that an average of three events occur every year, the potential emission of $6.4 \mathrm{E}+03 \mathrm{~kg}$ of $\mathrm{CO}_{2}$ eq. can be quickly compensated. The equivalent approach for sidewalks resulted in $84 \mathrm{~m}^{2}$. The impact category with the largest EP is MEP, resulting from the fertilizers required to produce the grass sod that was 
planted in the FSTs. In this case, the impacts were recovered when 15 cars and $1761 \mathrm{~m}^{2}$ of sidewalk were not destroyed.

Furthermore, results related to the NEI of the FSTs implemented to the case study neighborhood are shown in Table 2, as calculated according to Step 6. The impacts of the FSTs without accounting for the avoided burdens (A) and applying the NEI (B) were compared. The percentage reduction of the impact of the BMP per event varied in each impact category depending on their EP. Nonetheless, there were remarkable changes when calculating the NEI. For instance, the HTP could be reduced by almost $700 \%$ with respect to A given that the production of the metal parts of the car would be avoided. In contrast, there was an $8 \%$ reduction in MEP because this indicator had the lowest EP.

$<$ Table 2>

\section{DISCUSSION}

This first analysis showed an example of integrating damage prevention into the CLCA of a BMP. Uncertainty is relevant in CLCA and the number of effects that result from a decision might be incommensurable. In this case, we focused on the positive side of BMPs in the framework of flood prevention. However, there might be associated negative impacts, such as the creation of marginal demand for energy, fertilizers, mining, etc. related to the added pressure of producing FSTs. No further effects were accounted for, except for the marginal electricity generation, which resulted in very small variations in the environmental impacts (less than $1 \%$ ).

Only data related to a single event could be applied as a first step towards more complex studies at the watershed or city scale. Obtaining this type of data presents great difficulties, especially in 
the case of private property damage, as only when there is an insurance coverage, for instance, will the damage be reported. This means that the number of damaged products might be typically greater than that found in databases or official reports. Damage to buildings would be expected, especially in basements and electric and gas connections (U.S. Department of Commerce Economics and Statistics Administration Economist, 2013). However, there is a lack of studies that assess the environmental effects of material damage prevention and our results could not be validated. Recent models integrated hydraulic features and damage functions (Chen et al., 2016), and the difficulties in damage modeling were presented. The comparison between damage estimates and national expenditures also highlights great errors related to inaccurate estimations (Downton and Pielke, 2005). Uncertainty analyses might shed light to potential drivers for these errors, but we do not have sufficient high-quality data that could be applied to this type of assessment without adding more uncertainty to the results. Therefore, this first approach should be combined with robust predictive models in order to provide more information about the NEI of these systems.

Nevertheless, modeling consequences was out of the scope of this study. We illustrate how the environmental assessment of damage might provide more information about the benefits of green BMPs at a local scale. So far, the European Flood Directive (European Council, 2007) has resulted in policies that tend to promote non-structural strategies such as land use regulations. In this sense, investing in BMPs might not be attractive in certain areas, but decisions might change when further effects are considered. Here, we did not include an economic assessment because our goal was to highlight the environmental relevance of these decisions. However, the economic and environmental payback of these actions should be considered in future analyses. 
The outcome of this approach might be of interest in the field of communication and policymaking. We believe that urban planners, the administration and insurance companies might benefit from these results because they provide information about indirect consequences that might have a large impact on the society. For instance, managing green areas in low-density neighborhoods might be key to approaching a more sustainable urban model. The design of the FST could vary depending on the plot dimensions so as not to affect aesthetics and other functionalities, such as leisure or private use. Moreover, the design should comply with the technical requirements to prevent soil compaction and ensure the proper infiltration of stormwater. In addition, this multifunctional approach would also foster biodiversity and prevent a reduction in the ecological connectivity of the area.

\section{CONCLUSIONS}

This analysis provided a first insight into the environmental effects of integrating flood damage prevention into the LCA of BMPs. Our first example was based on a Brazilian residential neighborhood. The environmental payback of an FST was related to the prevention of at least one car or $84 \mathrm{~m}^{2}$ of sidewalk during 10 years, which is a short payback time considering the frequency of flooding events in the area. Subtracting the material damage of a historic flooding event to the potential environmental investment made for implementing a set of FSTs resulted in a net positive performance of these systems. The most favorable impact category was the HTP, as a gross estimate showed an impact reduction of almost $700 \%$.

Nevertheless, there are limitations in this analysis. When addressing this hydrological phenomenon, a risk assessment is needed to determine the frequency of this type of flooding event. Return periods, maximum water flows and population exposure, among other parameters, should 
be determined in a regional case study and included in the proposed methodology. In this way, the potential effect of the BMP on the water flow can be identified. Additional data are required regarding the material losses of the events. In this case, only a hypothetical analysis could be presented with data from a single flooding event with damage, but a statistical analysis would provide a more accurate idea in an attempt to generalize. However, it is currently very difficult to find registers for damage in specific locations and to predict future damage.

Future research should couple the economic value of the predicted material and ecological damage, risk assessment models and the environmental impacts of the BMPs. Hence, this approach would be of great interest to insurance companies and governments for the planning and reduction of their financial budget. Combined with the environmental implications of these events, decisionmakers and urban planners would be provided with more data for managing flooding risks.

\section{ACKNOWLEDGMENTS}

The authors thank the project HBP-2012-0216 funded by the Spanish (MECD) and Brazilian Governments (CAPES ref. 5206.). The authors would also like to thank the Spanish Ministry of Education for the grant awarded to A. Petit-Boix (FPU13/01273) to conduct this research, and the Catalan Government for the SGR funds (2014 SGR 1412). The authors acknowledge the financial support from the Spanish Ministry of Economy and Competitiveness, through the "María de Maeztu" program for Units of Excellence in R\&D (MDM-2015-0552).

\section{REFERENCES}

Angrill, S., Segura-Castillo, L., Petit-Boix, A., Rieradevall, J., Gabarrell, X., Josa, A., 2016. Environmental performance of rainwater harvesting strategies in Mediterranean buildings. Int. J. Life Cycle Assess. in press, 1-12. doi:10.1007/s11367-016-1174-x

Baptista, M., Nascimento, N., Barraud, S., 2005. Compensatory techniques in urban drainage 
(Técnicas compensatórias em Drenagem Urbana), Brazilian Association of Water Resources. Porto Alegre.

Catalano De Sousa, M., Erispaha, A., Spatari, S., Montalto, F., 2011. LCA as a Tool to Evaluate Green Infrastructure's Environmental Performance. Am. Geophys. Union.

Chen, A.S., Hammond, M.J., Djordjević, S., Butler, D., Khan, D.M., Veerbeek, W., 2016. From hazard to impact: flood damage assessment tools for mega cities. Nat. Hazards. doi:10.1007/s11069-016-2223-2

Czemiel Berndtsson, J., 2010. Green roof performance towards management of runoff water quantity and quality: A review. Ecol. Eng. 36, 351-360. doi:10.1016/j.ecoleng.2009.12.014

De Sousa, M.R.C., Montalto, F.A., Spatari, S., 2012. Using Life Cycle Assessment to Evaluate Green and Grey Combined Sewer Overflow Control Strategies. J. Ind. Ecol. 16, 901-913. doi:10.1111/j.1530-9290.2012.00534.x

Deletic, A., Fletcher, T.D., 2006. Performance of grass filters used for stormwater treatment-a field and modelling study. J. Hydrol. 317, 261-275. doi:10.1016/j.jhydrol.2005.05.021

Devkota, J., Schlachter, H., Apul, D., 2015. Life Cycle Based Evaluation of Harvested Rainwater Use in Toilets and for Irrigation. J. Clean. Prod. doi:10.1016/j.jclepro.2015.02.021

Dierkes, C., Kuhlmann, L., Kandasamy, J., Angelis, G., 2002. Pollution Retention Capability and Maintenance of Permeable Pavements, in: Global Solutions for Urban Drainage. ASCE, pp. $1-13$.

Downton, M.W., Pielke, R.A., 2005. How Accurate are Disaster Loss Data? The Case of U.S. Flood Damage. Nat. Hazards 35, 211-228. doi:10.1007/s11069-004-4808-4

Earles, J.M., Halog, A., 2011. Consequential life cycle assessment: a review. Int. J. Life Cycle Assess. 16, 445-453. doi:10.1007/s11367-011-0275-9

European Commission, 2013. Building a Green Infrastructure for Europe. European Union ISBN 978-92-79-33428-3.

European Council, 2007. Directive 2007/60/EC of the European Parliament and of the Council of 23 October 2007 on the assessment and management of flood risks.

FLOODsite, 2008. Intensity of rainfall [WWW Document]. URL http://www.floodsite.net/juniorfloodsite/html/en/student/thingstoknow/hydrology/rainfallint ensity.html (accessed 2.19.15).

Flynn, K.M., Traver, R.G., 2013. Green infrastructure life cycle assessment: A bio-infiltration case study. Ecol. Eng. 55, 9-22. doi:10.1016/j.ecoleng.2013.01.004

Frischknecht, R., Jungbluth, N., Althaus, H.-J., Doka, G., Dones, R., Heck, T., Hellweg, S., Hischier, R., Nemecek, T., Rebitzer, G., Spielmann, M., 2005. The ecoinvent database: Overview and methodological framework. Int. J. Life Cycle Assess. 10, 3-9.

Goedkoop, M., Heijungs, R., Huijbregts M, De Schryver A, Struijs J, Van Zelm, R., 2009. ReCiPe 2008, A Life Cycle Impact Assessment Method Which Comprises Harmonised Category Indicators at the Midpoint and the Endpoint Level. Report I: Characterisation, First Ed. ed. Available at: http://www.lcia-recipe.net. 
Google Maps, 2015. Res. Damha I - Google Maps [WWW Document]. URL https://www.google.es/maps/place/Res.+Damha+I,+SP,+Brazil/@-21.9642108,47.9018604,995m/data=!3m2!1e3!4b1!4m2!3m1!1s0x94b8705d8cf52391:0xd2a66e30c1e9 ecea $7.9018604,995 \mathrm{~m} /$ data $=! 3 \mathrm{~m} 2$ !1e $3 ! 4 \mathrm{~b} 1$ !4m2!3m1!1s0x94b8705d8cf52391:0xd2a66e30c 1e9ecea (accessed 2.19.15).

Guha-Sapir, D., Below, R., Hoyois, P., 2009. EM-DAT: International Disaster Database. Université Catholique de Louvain - Brussels - Belgium [WWW Document]. URL www.emdat.be Accessed December 2014

Hawkins, T.R., Singh, B., Majeau-Bettez, G., Strømman, A.H., 2013. Comparative Environmental Life Cycle Assessment of Conventional and Electric Vehicles. J. Ind. Ecol. 17, 53-64. doi:10.1111/j.1530-9290.2012.00532.x

Hischier, R., Weidema, B., Althaus, H., Bauer, C., Doka, G., Dones, R., Frischknecht, R., Hellweg, S., Humbert, S., Jungbluth, N., Köllner, T., Loerincik, Y., Margni, M., Nemecek, T., 2010. Implementation of Life Cycle Impact Assessment Methods. Final report ecoinvent v2.2 No. 3.

INMET. Instituto Nacional de Meteorologia, 2014. Daily accumulated rainfall of Sao Carlos 19612014 [WWW Document]. URL http://www.inmet.gov.br/portal/ Accessed October 2014

IPMet. Instituto de Pesquisas Meteorológicas, 2014. Natural Disaster Database (Banco de Dados de Desastres Naturais) [WWW Document]. URL http://www.ipmet.unesp.br/index2.php?abre=ipmet_html/defesa_civil/index.php Accessed January 2015

ISO 14040:2006, n.d. Environmental management - Life cycle assessment - Principles and framework.

Jha, A., Bloch, R., Lamond, J., 2012. Cities and Flooding. A Guide to Integrated Urban Flood Risk Management for the 21st Century. The World Bank, Washington, D.C.

Jha, A., Lamond, J., Bloch, R., Bhattacharya, N., Lopez, A., Papachristodoulou, N., Bird, A., Proverbs, D., Davies, J., Barker, R., 2011. Five Feet High and Rising. Cities and Flooding in the 21 st Century. Policy Research Working Paper.

Kosareo, L., Ries, R., 2007. Comparative environmental life cycle assessment of green roofs. Build. Environ. 42, 2606-2613. doi:10.1016/j.buildenv.2006.06.019

Lee, J.Y., Moon, H.J., Kim, T.I., Kim, H.W., Han, M.Y., 2013. Quantitative analysis on the urban flood mitigation effect by the extensive green roof system. Environ. Pollut. 181, 257-61. doi:10.1016/j.envpol.2013.06.039

Llopart-Mascaró A, Farreny, R, Gabarrell, X, Rieradevall, J, Gil, A, Martínez, M, Puertas, J, Suárez, J., Río, H., Paraira, M., 2015. Storm tank against combined sewer overflow: Operation strategies to minimise discharges impact to receiving waters. Urban Water J. 12, 219-228. doi:10.1080/1573062X.2013.868499

Lorenzo-Toja, Y., Vázquez-Rowe, I., Chenel, S., Marín-Navarro, D., Moreira, M.T., Feijoo, G., 2015. Eco-efficiency analysis of Spanish WWTPs using the LCA+DEA method. Water Res. 68, 651-666. doi:10.1016/j.watres.2014.10.040 
Lucas, A.H., 2011. Monitoramento e modelagem de um sistema filtro-vala-trincheira de infiltração em escala real. PhD Thesis. Universidade Federal de São Carlos.

Lucas, A.H., Barbassa, A.P., Moruzzi, R.B., 2013. Modelagem de um sistema filtro-vala-trincheira de infiltração pelo método de Puls adaptado para calibração de parâmetros. Rev. Bras. Recur. Hídricos 18, 135-236.

Meehl, G.A., Stocker, T.F., Collins, W.D., Friedlingstein, P., Gaye, A.T., Gregory, J.M., Kitoh, A., Knutti, R., Murphy, J.M., Noda, A., Raper, S.C.B., Watterson, I.G., Weaver, A.J., Zhao, Z.-C., 2007. Global Climate Projections. In: Climate Change 2007: The Physical Science Basis. Contribution of Working Group I to the Fourth Assessment Report of the Intergovernmental Panel on Climate Change [Solomon, S., D. Qin, M. Manning, Z. Chen, M. Marquis, K.B. A. Cambridge University Press, Cambridge, United Kingdom and New York, NY, USA.

Mendoza, J.-M., Oliver-Solà, J., Gabarrell, X., Rieradevall J, Josa, A., 2012. Planning strategies for promoting environmentally suitable pedestrian pavements in cities. Transp. Res. Part D Transp. Environ. 17, 442-450. doi:10.1016/j.trd.2012.05.008

Mentens, J., Raes, D., Hermy, M., 2006. Green roofs as a tool for solving the rainwater runoff problem in the urbanized 21st century? Landsc. Urban Plan. 77, 217-226. doi:10.1016/j.landurbplan.2005.02.010

Petit-Boix, A., Arahuetes, A., Josa, A., Rieradevall, J., Gabarrell, X., 2016. Are we preventing flood damage eco-efficiently? An integrated method applied to post-disaster emergency actions. Sci. Total Environ. doi:10.1016/j.scitotenv.2016.12.034

Petit-Boix, A., Sevigné-Itoiz, E., Rojas-Gutierrez, L.A., Barbassa, A.P., Josa, A., Rieradevall, J., Gabarrell, X., 2015. Environmental and economic assessment of a pilot stormwater infiltration system for flood prevention in Brazil. Ecol. Eng. 84, 194-201. doi:10.1016/j.ecoleng.2015.09.010

PRé Consultants, 2010. SimaPro 7.2.0. PRé Consultants, Amersfoort.

Risch, E., Loubet, P., Núñez, M., Roux, P., 2014. How environmentally significant is water consumption during wastewater treatment? Application of recent developments in LCA to WWT technologies used at 3 contrasted geographical locations. Water Res. 57, 20-30. doi:10.1016/j.watres.2014.03.023

Saiz, S., Kennedy, C., Bass, B., Pressnail, K., 2006. Comparative life cycle assessment of standard and green roofs. Environ. Sci. Technol. 40, 4312-6.

Sanchez, S.T., Woods, J., Akhurst, M., Brander, M., O’Hare, M., Dawson, T.P., Edwards, R., Liska, A.J., Malpas, R., 2012. Accounting for indirect land-use change in the life cycle assessment of biofuel supply chains. J. R. Soc. Interface 9, 1105-19. doi:10.1098/rsif.2011.0769

Schmidt, J.H., Thrane, M., 2009. Life cycle assessment of aluminium production in new Alcoa smelter in Greenland. Aalborg, Denmark.

Schweimer, G.W., Levin, M., 2000. Life Cycle Inventory for the Golf A4.

Sonnemann, G., Vigon, B., 2011. Global Guidance Principles for Life Cycle Assessment 
Databases. A basis for greener processes and products. UNEP SETAC, Life Cycle Initative.

Spatari, S., Yu, Z., Montalto, F. a, 2011. Life cycle implications of urban green infrastructure. Environ. Pollut. 159, 2174-9. doi:10.1016/j.envpol.2011.01.015

The World Bank, 2016. Urban population (\% of total). [WWW Document]. URL http://data.worldbank.org/indicator/SP.URB.TOTL.IN.ZS Accessed July 2014

U.S. Department of Commerce Economics and Statistics Administration Economist. Office of the Chief Economist, 2013. Economic impact of Hurricane Sandy. Potential economic activity lost and gained in New Jersey and New York. U.S. Department of Commerce.

UDFCD. Urban Drainage and Flood Control District, 2011. Urban Storm Drainage Criteria Manual Volume 3. Chapter 2: BMP Selection. Denver, US.

UN. United Nations. Department of Economic and Social Affairs. Population Division, 2012. World Urbanization Prospects: The 2011 Revision, CD-ROM Edition.

USDT. United States Department of Transportation, 2014. Stormwater Best Management Practices in an Ultra-Urban Setting: Selection and Monitoring [WWW Document]. URL http://environment.fhwa.dot.gov/ecosystems/ultraurb/ Accessed December 2014

Vázquez-Rowe, I., Marvuglia, A., Rege, S., Benetto, E., 2014. Applying consequential LCA to support energy policy: land use change effects of bioenergy production. Sci. Total Environ. 472, 78-89. doi:10.1016/j.scitotenv.2013.10.097

Wang, R., Eckelman, M.J., Zimmerman, J.B., 2013. Consequential environmental and economic life cycle assessment of green and gray stormwater infrastructures for combined sewer systems. Environ. Sci. Technol. 47, 11189-98. doi:10.1021/es4026547

Wang, R., Zimmerman, J.B., 2015. Economic and environmental assessment of office building rainwater harvesting systems in various U.S. cities. Environ. Sci. Technol. 49, 1768-78. doi: $10.1021 /$ es5046887

Weidema, B., Ekvall, T., Heijungs, R., 2009. Guidelines for application of deepened and broadened LCA. Co-ordination Action for innovation in Life-Cycle Analysis for Sustainability (CALCAS), Deliverable D18 of work package 5.

Wolf, M.-A., Ekvall, T., 2011. Life Cycle Inventory (LCI) Modelling and Attributional/Consequential Issues. SETAC Globe-Environmental Qual. through Sci. 12.

Zahmatkesh, Z., Burian, S.J., Karamouz, M., Tavakol-Davani, H., Goharian, E., 2015. LowImpact Development Practices to Mitigate Climate Change Effects on Urban Stormwater Runoff: Case Study of New York City. J. Irrig. Drain. Eng. 141, 4014043. doi:10.1061/(ASCE)IR.1943-4774.0000770

Zamagni, A., Guinée, J., Heijungs, R., Masoni, P., Raggi, A., 2012. Lights and shadows in consequential LCA. Int. J. Life Cycle Assess. 17, 904-918. doi:10.1007/s11367-012-0423-x 
Table 1 Unitary impacts of the FST, car and sidewalk and environmental payback of the FST

\begin{tabular}{|c|c|c|c|c|c|c|c|}
\hline & & & \multicolumn{3}{|c|}{ Total unitary impacts } & \multicolumn{2}{|c|}{$\begin{array}{l}\text { Environmental } \\
\text { payback (EP) }\end{array}$} \\
\hline \multicolumn{2}{|r|}{ Impact category } & Units & $1 \mathrm{FST}$ & $1 \mathrm{car}$ & $\begin{array}{c}1 \mathrm{~m}^{2} \\
\text { sidewalk }\end{array}$ & $\begin{array}{l}\text { Ratio } \\
\text { EST }\end{array}$ & $\begin{array}{c}\text { Ratio } \\
\text { FST- } \text { m }^{2}\end{array}$ \\
\hline $\mathrm{CC}$ & Climate Change & $\mathrm{kg} \mathrm{CO}_{2}$ eq. & $6.4 \mathrm{E}+03$ & $5.9 \mathrm{E}+03$ & $7.6 \mathrm{E}+01$ & 1.1 & 84 \\
\hline ODP & Ozone Depletion Potential & kg CFC-11 eq. & $9.0 \mathrm{E}-04$ & $5.7 \mathrm{E}-04$ & $6.4 \mathrm{E}-06$ & 1.6 & 142 \\
\hline TAP & Terrestrial Acidification Potential & $\mathrm{kg} \mathrm{SO}_{2}$ eq. & $1.9 \mathrm{E}+02$ & $2.9 \mathrm{E}+01$ & $2.3 \mathrm{E}-01$ & 6.5 & 824 \\
\hline FEP & Freshwater Eutrophication Potential & $\mathrm{kg} P$ eq. & $1.7 \mathrm{E}+00$ & $6.0 \mathrm{E}+00$ & 4.4E-03 & 0.3 & 385 \\
\hline MEP & Marine Eutrophication Potential & $\mathrm{kg} \mathrm{N}$ eq. & $2.2 \mathrm{E}+01$ & $1.5 \mathrm{E}+00$ & $1.3 \mathrm{E}-02$ & 15 & 1,761 \\
\hline HTP & Human Toxicity Potential & kg 1,4-DB eq. & $1.6 \mathrm{E}+03$ & $1.1 \mathrm{E}+04$ & $6.2 \mathrm{E}+00$ & 0.1 & 259 \\
\hline PCOP & $\begin{array}{l}\text { Photochemical Oxidant Formation } \\
\text { Potential }\end{array}$ & kg NMVOC & $5.7 \mathrm{E}+01$ & $1.7 \mathrm{E}+01$ & 3.6E-01 & 3.3 & 160 \\
\hline WDP & Water Depletion Potential & $\mathrm{m}^{3}$ & $1.7 \mathrm{E}+02$ & $6.7 \mathrm{E}+01$ & $9.5 \mathrm{E}-01$ & 2.5 & 176 \\
\hline MDP & Metal Depletion Potential & kg Fe eq. & $1.8 \mathrm{E}+03$ & $5.0 \mathrm{E}+03$ & $1.8 \mathrm{E}+00$ & 0.4 & 1,006 \\
\hline FDP & Fossil Depletion Potential & $\mathrm{kg}$ oil eq. & $2.4 \mathrm{E}+03$ & $1.7 \mathrm{E}+03$ & $1.5 \mathrm{E}+01$ & 1.4 & 159 \\
\hline CED & Cumulative Energy Demand & MJ & $3.2 \mathrm{E}+05$ & $1.0 \mathrm{E}+05$ & $7.5 \mathrm{E}+02$ & 3.2 & 427 \\
\hline
\end{tabular}

Table 2 NEI per event of the implementation of FSTs in RDI, considering 179 FSTs, 6 cars, 150 $\mathrm{m}^{2}$ of sidewalk and an average of 3 intense flooding events per year.

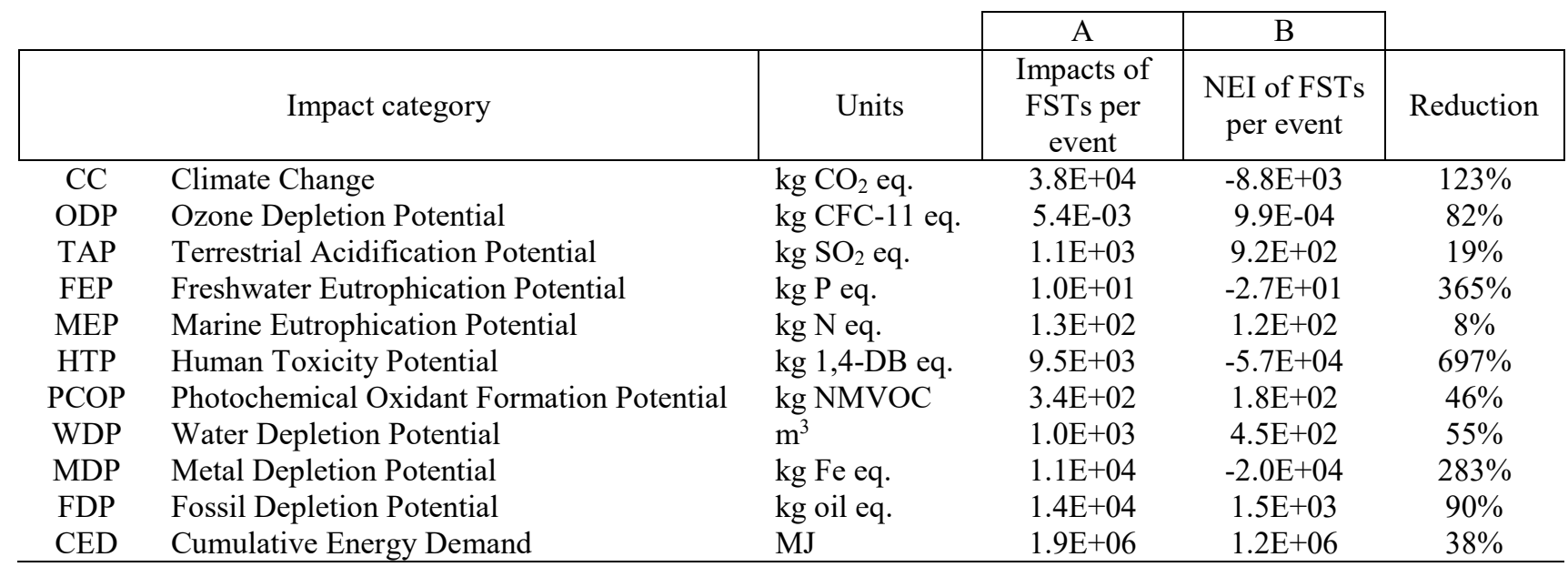


Figure 1 Consequences of implementing BMPs for flood prevention and integration into the CLCA framework and steps for calculating the EP and NEI

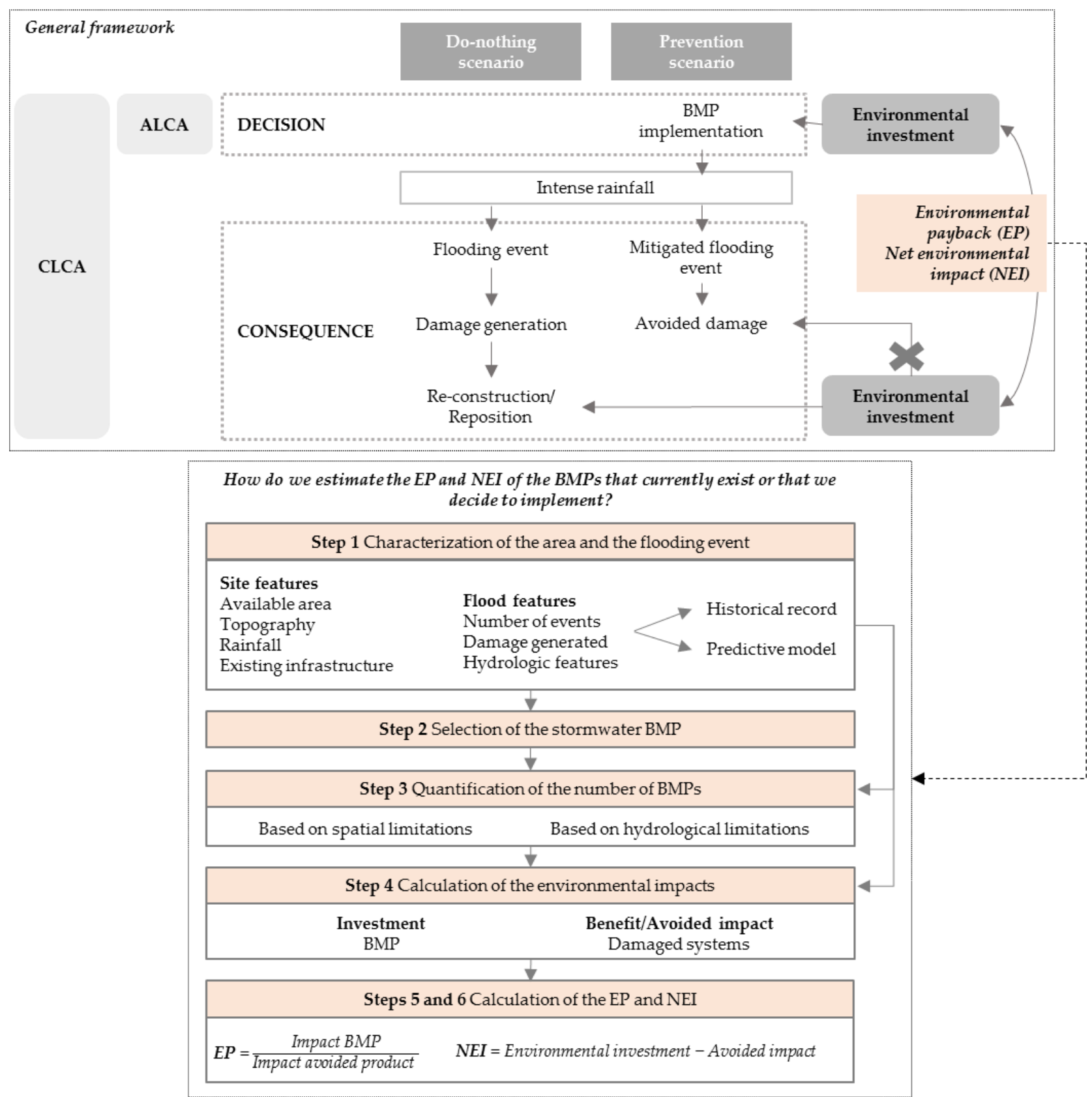




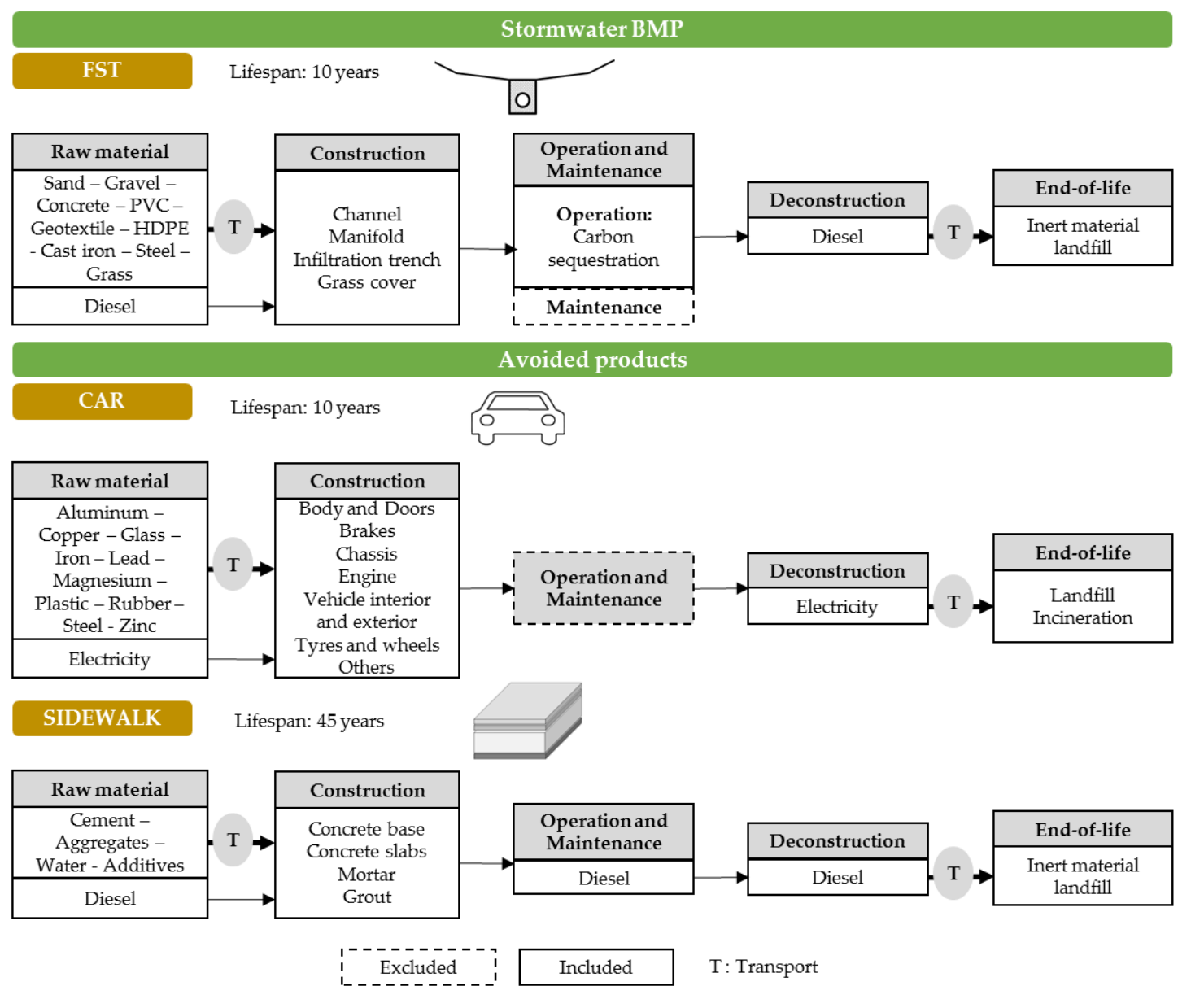

Figure 2 System boundaries of the systems under analysis: FST, car and sidewalk 